\title{
Synthesis, characterization and spectrochemical studies on a few binuclear $\mu$-oxo molybdenum(V) complexes of pyrimidine derived Schiff base ligands
}

\author{
SAMIK GUPTA ${ }^{a}$, SOMNATH ROY ${ }^{a}$, TARAK NATH MANDAL ${ }^{\mathrm{a}}$, KINSUK DAS $^{\mathrm{b}}$, \\ SANGITA RAY ${ }^{\mathrm{a}}$, RAY J BUTCHER $^{\mathrm{c}}$ and SUSANTA KUMAR KAR ${ }^{\mathrm{a}, *}$ \\ ${ }^{a}$ Department of Chemistry, University College of Science, 92 A.P.C. Road, Kolkata 700009 \\ ${ }^{b}$ Department of Chemistry, Haldia Government College, Debhog, Purba, Midnapur 721657 \\ ${ }^{\mathrm{c}}$ Department of Chemistry, Howard University, 2400 Sixth Street, N.W., Washington, DC 20059, USA \\ e-mail: skkar_cu@yahoo.co.in
}

MS received 28 April 2009; revised 2 July 2009; accepted 29 July 2009

\begin{abstract}
Ten new binuclear singly oxo-bridged molybdenum complexes (complexes 1-10) were prepared using five pyrimidine derived Schiff base ligands and two $\mathrm{Mo}(\mathrm{V})$ precursors $\left(\mathrm{NH}_{4}\right)_{2} \mathrm{MoOCl}_{5}$ and $\left(\mathrm{NH}_{4}\right)_{2} \mathrm{MoOBr}_{5}$. The ligands are prepared by the condensation of 4,6-dimethyl 2-hydrazino pyrimidine with salicylaldehyde (for $\mathrm{HL}_{1}$ ), $o$-hydroxy acetophenone (for $\mathrm{HL}_{2}$ ) and substituted salicylaldehydes (for $\mathrm{HL}_{3}, \mathrm{HL}_{4}$ and $\mathrm{HL}_{5}$ ) respectively. These ligands are already reported as good donors for Mo(VI) state. The $\mu$-oxo $\mathrm{Mo}(\mathrm{V})$ complexes reported here bears a distorted octahedral geometry around each Mo atom with either $\mathrm{N}_{2} \mathrm{O}_{2} \mathrm{Cl}$ or $\mathrm{N}_{2} \mathrm{O}_{2} \mathrm{Br}$ chromophores. Fine variations in the spectroscopic behaviour of the complexes are observed in accordance with the varying electron donating properties of the ligands. All the complexes are unstable in solution and X-ray quality crystal of complex $\mathbf{1}$ could be isolated. All the complexes are characterized by IR and UV-Vis spectra.
\end{abstract}

Keywords. Molybdenum(V); Schiff base; crystal structure; binuclear complex; spectral study.

\section{Introduction}

The chemistry of molybdenum is quite interesting because of its large number of accessible oxidation states as well as its ability to form stable complexes with oxygen, nitrogen and sulphur containing ligands with diverse coordination numbers and stereochemistries. ${ }^{1}$ Perhaps this versatility is what qualifies it for use by nature in various essential life processes as constituent part of several metalloenzymes. ${ }^{2}$ In fact, Mo is the only essential trace element of the second transition series and is an integral part of oxotransferase $^{3}$ and nitrogenase enzymes. ${ }^{4}$

Several molybdoenzymes consist of two Mo atoms per molecule suggesting binuclear Mo sites and joined by one or two oxo or sulphido bridges. The Mo atom alternates +VI and +IV states with the involvement of transient $\mathrm{Mo}(\mathrm{V})$ state also. ${ }^{5}$ Though the active site of the fully oxidized $\left(\mathrm{Mo}^{6+}\right)$ and reduced form $\left(\mathrm{Mo}^{4+}\right)$ of metalloenzymes has already

\footnotetext{
*For correspondence
}

been determined crystallographically the understanding of the transient $\mathrm{Mo}(\mathrm{V})$ state is still heavily dependant on spectroscopy. ${ }^{6}$ With the knowledge of approximate coordination sphere of Mo in the metalloenzymes at hand, several attempts have been made to model the active sites of these enzymes and study their enzyme mimetic activity. From the last quarter of twentieth century the literature has been flooded with reports of model complexes mostly containing the Mo(VI) state and Schiff base ligands. ${ }^{7}$ The Mo(V) complexes are less described and compared to the Mo(VI) species. In fact, up to the first half of this decade only a few crystal structures of $\mathrm{Mo}(\mathrm{V})$ complexes with Schiff bases ${ }^{8}$ could be found at the Cambridge structural Database (version 5.26, November 2004). ${ }^{9}$ The chemistry of $\mathrm{Mo}(\mathrm{V})$ is dominated by spin paired oxo-bridged dimers with $\mathrm{Mo}_{2} \mathrm{O}_{3}^{4+}$ or $\mathrm{Mo}_{2} \mathrm{O}_{4}^{2+}$ cores. Mononuclear paramagnetic $\mathrm{Mo}(\mathrm{V})$ complexes are not so common in literature. Because of a tendency of $\mathrm{Mo}(\mathrm{V})$ species to form oxo-bridged binuclear complexes preparation of mononuclear complexes requires careful choice of the ligands 
which stereochemically hinders formation of binuclear Mo core. ${ }^{10}$ In nature, however, the pterin bound enzymes such as DMSO reductase are common in microbial systems and are mononuclear in nature. ${ }^{11}$

Apart from their utility as model compounds for enzymes the Mo(V) complexes have also found use as catalysts for oxygen transfer. $\mathrm{Mo}(\mathrm{V})$ complexes are known to 'speed up' the transfer of oxygen from DMSO or pyridine-N-oxide to triphenyl phosphine. $^{12}$

In the present work, we have continued our endeavour to explore the chemistry of Mo complexes with heterocycle based ligands and synthesized ten new $\mu$-oxo binuclear Mo complexes of pyrimidine derived Schiff base ligands. These complexes are prepared from two standard $\mathrm{Mo}(\mathrm{V})$ precursors $\left(\mathrm{NH}_{4}\right)_{2} \mathrm{MoOCl}_{5}$ and $\left(\mathrm{NH}_{4}\right)_{2} \mathrm{MoOBr}_{5}$. The complexes bear octahedral arrangement about each Mo center using the tridentate NNO donor ligand, two oxo groups (one terminal and the other bridging) and a loosely bound halide moiety. Previously we have shown that difference in electron donating abilities of Schiff base ligands affect the spectroscopic properties in the corresponding Mo(VI) complexes with justifiable correlations. ${ }^{13}$ Here also, we have found that similar effects are observed for a series of $\mathrm{Mo}(\mathrm{V})$ complexes.

\section{Experimental}

$\left(\mathrm{NH}_{4}\right)_{2} \mathrm{MoOCl}_{5}$ and $\left(\mathrm{NH}_{4}\right)_{2} \mathrm{MoOBr}_{5}$ were prepared as described in the literature. ${ }^{14}$ Reagent grade solvents were used as received. 4,6-dimethyl 2-hydrazino pyrimidine was prepared as described in the literature. ${ }^{15}$ Salicylaldehyde, 5-bromo salicylaldehyde 5-chlorosalicylaldehyde, 5-nitrosalicylaldehyde and $o$-hydroxyacetophenone were purchased from Aldrich Chemical Company, USA and used as received. The ligands $\mathrm{HL}_{1}, \mathrm{HL}_{2}$ were prepared as described in our previous publication. ${ }^{16} \mathrm{HL}_{3}, \mathrm{HL}_{4}$ and $\mathrm{HL}_{5}$ were prepared using a similar technique by condensation of $10 \mathrm{mmol}$ of 5-bromo salicylaldehyde 5-chlorosalicylaldehyde or 5-nitrosalicylaldehyde with $10 \mathrm{mmol}$ of 4,6-dimethyl 2-hydrazino pyrimidine in each case.

$\mathrm{HL}_{3}$ : m.p. $167^{\circ} \mathrm{C}$. Yield: $2.68 \mathrm{~g}(80 \%)$. IR $(\mathrm{KBr}$ pellet) $v / \mathrm{cm}^{-1}: 3321(\mathrm{~N}-\mathrm{H}), 3187(\mathrm{O}-\mathrm{H}), 1535.2$ $(\mathrm{C}=\mathrm{N}), 1612(\mathrm{C}=\mathrm{C}) .{ }^{1} \mathrm{H}$ NMR $\left(300 \mathrm{MHz}, \mathrm{CDCl}_{3}\right.$, $25^{\circ} \mathrm{C}$, TMS $\delta / \mathrm{ppm}:(6.62)\left(\mathrm{s}, 1 \mathrm{H},-\mathrm{C}_{5}-\mathrm{H}\right.$ Pyrimidine), (6.9-7.6) $\left(m, 4 \mathrm{H},-\mathrm{C}_{6} \mathrm{H}_{4}\right),(8.2)(s, 1 \mathrm{H}$, $-\mathrm{CH}=\mathrm{N}-),(12.8)(s, 1 \mathrm{H}$, aromatic- $\mathrm{OH}),(2 \cdot 28)(s$, $1 \mathrm{H},\left(\mathrm{N}-\mathrm{H}\right.$ of hydrazone), (2.46-2.53) $\left(m, 6 \mathrm{H}, \mathrm{CH}_{3}\right)$.
$\mathrm{HL}_{4}$ : m.p. $165^{\circ} \mathrm{C}$ Yield: $1.70 \mathrm{~g}(60 \%)$. IR $(\mathrm{KBr}$ pellet) $v / \mathrm{cm}^{-1}: 3275(\mathrm{~N}-\mathrm{H}), 3191(\mathrm{O}-\mathrm{H}), 1528(\mathrm{C}=\mathrm{N})$, $1610(\mathrm{C}=\mathrm{C}) .{ }^{1} \mathrm{H}$ NMR $\left(300 \mathrm{MHz}, \mathrm{CDCl}_{3}, 25^{\circ} \mathrm{C}, \mathrm{TMS}\right)$ $\delta / \mathrm{ppm}:(6.63)\left(s, 1 \mathrm{H},-\mathrm{C}_{5}-\mathrm{H}\right.$ pyrimidine $),(6.9-7.8)$ $\left(m, 4 \mathrm{H},-\mathrm{C}_{6} \mathrm{H}_{4}\right),(8 \cdot 2) \quad(s, 1 \mathrm{H},-\mathrm{CH}=\mathrm{N}-),(12 \cdot 8)$ $(s, 1 \mathrm{H}$, aromatic- $\mathrm{OH}),(2 \cdot 28)(s, 1 \mathrm{H}, \mathrm{N}-\mathrm{H}$ of hydrazone), (2.46-2.53) $\left(m, 6 \mathrm{H},\left(\mathrm{CH}_{3}\right)\right.$.

$\mathrm{HL}_{5}$ : m.p.: above $200^{\circ} \mathrm{C}$ Yield: $2.28 \mathrm{~g}(80 \%) .3321$ $(\mathrm{N}-\mathrm{H}), 3187(\mathrm{O}-\mathrm{H}), 1535.2(\mathrm{C}-\mathrm{N}), 1612(\mathrm{C}=\mathrm{C}) .{ }^{1} \mathrm{H}$ NMR (300 MHz, $\left.\mathrm{CDCl}_{3}, 25^{\circ} \mathrm{C}, \mathrm{TMS}\right) \delta / \mathrm{ppm}:(6.62)$ $\left(s, 1 \mathrm{H},-\mathrm{C}_{5}-\mathrm{H}\right.$ pyrimidine), (6.9-7.6) $\left.m, 4 \mathrm{H},-\mathrm{C}_{6} \mathrm{H}_{4}\right)$, $(8 \cdot 2)(s, 1 \mathrm{H},-\mathrm{CH}=\mathrm{N}-),(12 \cdot 8)(s, 1 \mathrm{H}$, aromatic- $\mathrm{OH})$, $(2.28)(s, 1 \mathrm{H}, \mathrm{N}-\mathrm{H}$ of hydrazone), (2.46-2.53) $\left(m, 6 \mathrm{H}, \mathrm{CH}_{3}\right)$.

\subsection{Synthesis of the complexes $\mathbf{1 - 1 0}$}

The complexes $\left[\mathrm{Mo}_{2} \mathrm{O}_{3}\left(\mathrm{~L}_{1}\right)_{2} \mathrm{Cl}_{2}\right] \quad(\mathbf{1}), \quad\left[\mathrm{Mo}_{2} \mathrm{O}_{3}\right.$ $\left.\left(\mathrm{L}_{2}\right)_{2} \mathrm{Cl}_{2}\right](2),\left[\mathrm{Mo}_{2} \mathrm{O}_{3}\left(\mathrm{~L}_{3}\right)_{2} \mathrm{Cl}_{2}\right](3),\left[\mathrm{Mo}_{2} \mathrm{O}_{3}\left(\mathrm{~L}_{4}\right)_{2} \mathrm{Cl}_{2}\right]$ (4) and $\left[\mathrm{Mo}_{2} \mathrm{O}_{3}\left(\mathrm{~L}_{5}\right)_{2} \mathrm{Cl}_{2}\right]$ (5) were synthesized by adding an ethanolic solution $(10 \mathrm{~mL})$ of $\left(\mathrm{NH}_{4}\right)_{2}$ $\mathrm{MoOCl}_{5}(0.5 \mathrm{mmol}, 0.160 \mathrm{~g})$ as the common reagent with ethanolic solutions of $\mathrm{HL}_{1}(0.5 \mathrm{mmol}, 0.122 \mathrm{~g})$, $\mathrm{HL}_{2}(0.5 \mathrm{mmol}, 0.136 \mathrm{~g}), \mathrm{HL}_{3}(0.5 \mathrm{mmol}, 0.201 \mathrm{~g})$ and $\mathrm{HL}_{4}(0.5 \mathrm{mmol}, 0.158 \mathrm{~g})$ and $\mathrm{HL}_{5}(0.5 \mathrm{mmol}$, $0 \cdot 167 \mathrm{~g})$ respectively. A deep magenta colouration of the solution developed immediately on mixing the two components. The respective complex separated as a violet microcrystalline compound on refluxing the reaction mixture for $15 \mathrm{~min}$ at water bath temperature. It was filtered, washed with ethanol and dried over fused $\mathrm{CaCl}_{2}$.

$\mathrm{X}$-ray quality crystals of $\mathbf{1}$ were grown by slow diffusion of a dilute ethanolic solution of $\left(\mathrm{NH}_{4}\right)_{2}$ $\mathrm{MoOCl}_{5}$ into a dilute ethanolic solution of ligand $\mathrm{HL}_{1}$ in a sealed glass tube. When the solution of the two precursors diffused into one another crystals of 6 formed and deposited on the inner wall of the glass tube.

Preparation of complexes 6-10 were affected by taking equimolar proportion of $\left(\mathrm{NH}_{4}\right)_{2} \mathrm{MoOBr}_{5}$ and the respective ligands and applying the same method.

$\left[\mathrm{Mo}_{2} \mathrm{O}_{3}\left(\mathrm{~L}_{1}\right)_{2} \mathrm{Cl}_{2}\right]$ (1): Yield $0 \cdot 130 \mathrm{~g}$ (33\%). Elemental analysis: Anal. Calc. (\%) for $\mathrm{C}_{26} \mathrm{~N}_{8} \mathrm{O}_{5} \mathrm{H}_{26}$ $\mathrm{Mo}_{2} \mathrm{Cl}_{2}: \mathrm{C}: 39.39 \mathrm{H}: 3.28 \mathrm{~N}: 14 \cdot 14$; Found C: $38 \cdot 91 \mathrm{H}: 3 \cdot 25 \mathrm{~N}: 14 \cdot 05$.

$\left[\mathrm{Mo}_{2} \mathrm{O}_{3}\left(\mathrm{~L}_{2}\right)_{2} \mathrm{Cl}_{2}\right]$ (2): Yield $0.143 \mathrm{~g}$ (35\%). Elemental analysis: Anal. Calc. (\%) for $\mathrm{C}_{28} \mathrm{~N}_{8} \mathrm{O}_{5}$ $\mathrm{H}_{30} \mathrm{Mo}_{2} \mathrm{Cl}_{2}$ : C: $40.97 \mathrm{H}: 3.65 \mathrm{~N}: 13.65$; Found C: 40.61H: $3.52 \mathrm{~N}: 13 \cdot 30$. 
$\left[\mathrm{Mo}_{2} \mathrm{O}_{3}\left(\mathrm{~L}_{3}\right)_{2} \mathrm{Cl}_{2}\right]$ (3): Yield $0 \cdot 166 \mathrm{~g}$ (35\%). Elemental analysis: Anal. Calc. (\%) for $\mathrm{C}_{26} \mathrm{~N}_{8} \mathrm{O}_{5} \mathrm{H}_{24}$ $\mathrm{Mo}_{2} \mathrm{Cl}_{2} \mathrm{Br}_{2}: \mathrm{C}: 32.84 \mathrm{H}: 2.52 \mathrm{~N}: 11.78$; Found $\mathrm{C}$ : $32 \cdot 45 \mathrm{H}: 2 \cdot 38 \mathrm{~N}: 11 \cdot 50$.

$\left[\mathrm{Mo}_{2} \mathrm{O}_{3}\left(\mathrm{~L}_{4}\right)_{2} \mathrm{Cl}_{2}\right](4)$ : Yield $0 \cdot 129 \mathrm{~g}$ (35\%). Elemental analysis: Anal. Calc. (\%) for $\mathrm{C}_{26} \mathrm{~N}_{8} \mathrm{O}_{5} \mathrm{H}_{24}$ $\mathrm{Mo}_{2} \mathrm{Cl}_{4}: \mathrm{C}: 36 \cdot 23 \mathrm{H}: 2 \cdot 78 \mathrm{~N}: 13.00$; Found C: $35.91 \mathrm{H}$ : $2 \cdot 65 \mathrm{~N}: 12 \cdot 70$.

$\left[\mathrm{Mo}_{2} \mathrm{O}_{3}\left(\mathrm{~L}_{5}\right)_{2} \mathrm{Cl}_{2}\right](5)$ : Yield $0 \cdot 132 \mathrm{~g}(30 \%)$. Elemental analysis: Anal. Calc. (\%) for $\mathrm{C}_{26} \mathrm{~N}_{10} \mathrm{O}_{9} \mathrm{H}_{24}$ $\mathrm{Mo}_{2} \mathrm{Cl}_{2}: \mathrm{C}: 35 \cdot 37 \mathrm{H}: 2 \cdot 72 \mathrm{~N}: 15 \cdot 87$; Found C: $35 \cdot 33 \mathrm{H}$ : $2 \cdot 61 \mathrm{~N}: 15 \cdot 66$.

$\left[\mathrm{Mo}_{2} \mathrm{O}_{3}\left(\mathrm{~L}_{1}\right)_{2} \mathrm{Br}_{2}\right]$ (6): Yield $0 \cdot 132 \mathrm{~g}$ (30\%). Elemental analysis: Anal. Calc. (\%) for $\mathrm{C}_{26} \mathrm{~N}_{8} \mathrm{O}_{5} \mathrm{H}_{26}$ $\mathrm{Mo}_{2} \mathrm{Br}_{2}: \mathrm{C}: 35.45 \mathrm{H}: \quad 3.40 \mathrm{~N}: 12.72$; Found $\mathrm{C}$ : $35 \cdot 51 \mathrm{H}: 3 \cdot 27 \mathrm{~N}: 12 \cdot 50$.

$\left[\mathrm{Mo}_{2} \mathrm{O}_{3}\left(\mathrm{~L}_{2}\right)_{2} \mathrm{Br}_{2}\right]$ (7): Yield $0 \cdot 159 \mathrm{~g}(35 \%)$. Elemental analysis: Anal. Calc. (\%) for $\mathrm{C}_{28} \mathrm{~N}_{8} \mathrm{O}_{5} \mathrm{H}_{30}$ $\mathrm{Mo}_{2} \mathrm{Br}_{2}$ : C: $37 \cdot 00 \mathrm{H}: 3.30 \mathrm{~N}: 12.33$; Found C: 36.90H: $3 \cdot 22 \mathrm{~N}: 12 \cdot 30$.

$\left[\mathrm{Mo}_{2} \mathrm{O}_{3}\left(\mathrm{~L}_{3}\right)_{2} \mathrm{Br}_{2}\right](8)$ : Yield $0 \cdot 182 \mathrm{~g}$ (35\%). Elemental analysis: Anal. Calc. (\%) for $\mathrm{C}_{26} \mathrm{~N}_{8} \mathrm{O}_{5} \mathrm{H}_{24}$ $\mathrm{Mo}_{2} \mathrm{Br}_{4}: \mathrm{C}: 30.05 \mathrm{H}: 2.31 \mathrm{~N}: 10.78$; Found $\mathrm{C}$ : 29.61H: $2 \cdot 29 \mathrm{~N}: 10 \cdot 30$.

$\left[\mathrm{Mo}_{2} \mathrm{O}_{3}\left(\mathrm{~L}_{4}\right)_{2} \mathrm{Br}_{2}\right]$ (9): Yield $0 \cdot 166 \mathrm{~g}(35 \%)$. Elemental analysis: Anal. Calc. (\%) for $\mathrm{C}_{26} \mathrm{~N}_{8} \mathrm{O}_{5} \mathrm{H}_{24}$ $\mathrm{Mo}_{2} \mathrm{Cl}_{2} \mathrm{Br}_{2}: \mathrm{C}: 32.80 \mathrm{H}: 2.78 \mathrm{~N}: 11.77$; Found C: 32.51H: $2 \cdot 61 \mathrm{~N}: 11 \cdot 41$.

$\left[\mathrm{Mo}_{2} \mathrm{O}_{3}\left(\mathrm{~L}_{5}\right)_{2} \mathrm{Br}_{2}\right] \quad(\mathbf{1 0}):$ Yield $0.145 \mathrm{~g} \quad(30 \%)$. Elemental analysis: Anal. Calc. (\%) for $\mathrm{C}_{26} \mathrm{~N}_{10} \mathrm{O}_{9} \mathrm{H}_{24}$ $\mathrm{Mo}_{2} \mathrm{Br}_{2}:$ C: $32 \cdot 16 \mathrm{H}: 2 \cdot 47 \mathrm{~N}: 14.43$; Found C: $32 \cdot 04 \mathrm{H}: 2 \cdot 30 \mathrm{~N}: 14 \cdot 52$.

\subsection{Physical measurements}

Elemental analyses $(\mathrm{C}, \mathrm{H}$ and $\mathrm{N})$, IR spectra $(\mathrm{KBr}$ discs, 4000-200 $\mathrm{cm}^{-1}$ ), of the ligands and the complexes and UV-Vis spectra (DMF)of the complexes were done with a Perkin-Elmer Model $240^{\circ} \mathrm{C} \mathrm{CHN}$ analyzer, a Jasco FTIR model 420 spectrophotometer and a Hitachi U-3501 spectrophotometer, respectively. Cyclic voltammetry (CV) experiments were carried out using Sycopel Model 77 AEW2 $1820 \mathrm{~F} / \mathrm{S}$ instrument. The measurements were performed at $300 \mathrm{~K}$ in a DMF solution containing $0 \cdot 2 \mathrm{M}$ TEAP and $10^{-3}-10^{-4} \mathrm{M} \mathrm{Mo}(\mathrm{VI})$ complexes 15 and 11 deoxygenated by bubbling with nitrogen. A platinum wire, a platinum coil and a SCE were used as a working, a counter and reference electrodes, respectively. Magnetic susceptibility measurements for complex 1 was carried out on polycrystalline samples, at the Servei de Magnetoquímica of the Universitat de Barcelona, with a Quantum Design SQUID MPMS-XL susceptometer apparatus working in the range $2-300 \mathrm{~K}$ under magnetic field of approximately $500 \mathrm{G}(2-30 \mathrm{~K})$ and $1000 \mathrm{G}$ (35$300 \mathrm{~K})$. Diamagnetic corrections were estimated from Pascal tables. The EPR spectra on 1-10 have been recorded on X-band Bruker Spectrometer (ESR $300 \mathrm{E}$ ), working with an oxford helium liquid cryostat for variable temperature.

\subsection{Crystallographic measurement}

The crystal of complex 1 was measured on an EnrafNonius CAD-4 diffractometer using $\mathrm{MoK} \alpha$ radiation $(\lambda=0.71073 \AA)$ and a graphite monochromator at $-80^{\circ} \mathrm{C}$. The unit cell dimensions were obtained from a least squares fit to the setting angles of 25 , accurately determined reflections. The data were collected using a $\omega-2 \theta$ scan technique with a $2 \theta$ range of $4-55^{\circ}$ and were corrected by an empirical method for absorption and Lorentz and polarization effect. Calculations were carried out using a XCAD49 (data reduction), SHELXTL (absorption corrections, structure solution refinements and molecular graphics). The structures were solved using direct methods and refined on $F^{2}$ using full matrix least squares techniques with anisotropic displacement factors for all non-hydrogen atoms. Positions of the Hydrogen atom were calculated from the geometry of the molecular skeleton and their thermal displacement parameters were refined isotropically on a group-wise basis. Crystal parameters of complex 1 are provided in table 1. Selected bond distances and bond angles are provided in table 2 .

\section{Results and discussion}

\subsection{Synthesis and spectroscopic analysis}

The ligands $H L_{\mathrm{n}}(n=1-5)$ have been used to prepare the $\mu$-oxo molybdenum(V) complexes $\mathbf{1 - 5}$ by reacting them with the $\mathrm{Mo}(\mathrm{V})$ precursor $\left(\mathrm{NH}_{4}\right)_{2} \mathrm{MoOCl}_{5}$. Similarly, using $\left(\mathrm{NH}_{4}\right)_{2} \mathrm{MoOBr}_{5}$ with the same series of ligands complexes 6-10 were prepared (scheme 1). All the ligands despite of their varying e donating ability, are found to be good donors towards both $\mathrm{Mo}(\mathrm{V})$ species. The reaction between the metal precursors and ligand solutions take place with immediate colour change at room temperature and precipitation of the respective complexes within an hour. 
The complexes are spin paired oxo-bridged binuclear units. The binuclear nature of the complexes is a result of an inherent property of the $\mathrm{Mo}(\mathrm{V})$ that it is inclined to produce oxo-bridged complexes with $\mathrm{Mo}_{2} \mathrm{O}_{3}^{4+}$ or $\mathrm{Mo}_{2} \mathrm{O}_{4}^{2+}$ cores, often regardless of the ligands used. Mononuclear complexes of $\mathrm{Mo}(\mathrm{V})$ are comparatively less described. Changes in the reaction conditions such as carrying out the reactions at room temperature did not alter the composition of the products. Characterization of these complexes was however hampered considerably by their low solubility in common organic solvents and their low stability in oxygenated solvents as DMF and DMSO. IR spectra of the ligands $\left(\mathrm{HL}_{\mathrm{n}}, n=1-5\right)$ show broad bands at $3170-3191 \mathrm{~cm}^{-1}$ for $\mathrm{H}$-bonded $v(\mathrm{O}-\mathrm{H})$

Table 1. Crystal parameters for complex 1.

\begin{tabular}{|c|c|}
\hline Identification code & Complex 6 \\
\hline Empirical formula & $\mathrm{C}_{26} \mathrm{H}_{26} \mathrm{C}_{12} \mathrm{Mo}_{2} \mathrm{~N}_{8} \mathrm{O}_{5}$ \\
\hline Formula weight & $793 \cdot 33$ \\
\hline Temperature (K) & $203(2)$ \\
\hline Wavelength $(\AA)$ & 0.71073 \\
\hline Crystal system & Orthorhombic \\
\hline Space group & Pnca \\
\hline Unit cell dimensions & $\begin{array}{l}a=15 \cdot 3153(5) \AA \\
\alpha=90^{\circ} \\
b=13 \cdot 7183(6) \AA \\
\beta=90^{\circ} \\
c=14 \cdot 1143(5) \AA \\
\gamma=90^{\circ}\end{array}$ \\
\hline Volume $\left(\AA^{3}\right)$ & $2965 \cdot 41(19)$ \\
\hline$Z$ & 8 \\
\hline Density (calc) $\left(\mathrm{gm} / \mathrm{cm}^{3}\right)$ & 1.777 \\
\hline Absorption coefficient $\left(\mathrm{mm}^{-1}\right)$ & 1584 \\
\hline$F(000)$ & 1584 \\
\hline Crystal size $\left(\mathrm{mm}^{3}\right)$ & $0.55 \times 0.43 \times 0.31$ \\
\hline Thetarange for data collection & 4.77 to $30.63^{\circ}$ \\
\hline Index ranges & $\begin{array}{l}-21 \leq h \leq 21 \\
-19 \leq k \leq 15 \\
-20 \leq 1 \leq 18\end{array}$ \\
\hline Reflections collected & 17220 \\
\hline Independent reflections & $4195[R($ int $)=0 \cdot 0481]$ \\
\hline Completeness to theta & $98.9 \%$ \\
\hline Absorption correction & $\begin{array}{l}\text { Semi-empirical from } \\
\text { equivalents }\end{array}$ \\
\hline Max. and min. transmission & 1.00000 and 0.70959 \\
\hline Refinement method & $\begin{array}{l}\text { Full-matrix least- } \\
\text { squares on } F 2\end{array}$ \\
\hline Data/restraints/parameters & $4195 / 0 / 197$ \\
\hline Goodness-of-fit on $F^{2}$ & $0 \cdot 998$ \\
\hline Final $R$ indices & $\begin{array}{l}R 1=0.0404 \\
w R 2=0.0905\end{array}$ \\
\hline $\begin{array}{l}{[I>2 \operatorname{sigma}(I)] R \text { indices }} \\
\quad \text { (all data) }\end{array}$ & $\begin{array}{l}R 1=0.0904 \\
w R 2=0 \cdot 1075\end{array}$ \\
\hline $\begin{array}{l}\text { Largest diff. peak } \\
\quad \text { and hole }\left(\mathrm{e} \AA^{-3}\right)\end{array}$ & 0.708 and -0.868 \\
\hline
\end{tabular}

stretch. The peaks for $v(\mathrm{~N}-\mathrm{H})$ of hydrazone are observed at $3275-3321 \mathrm{~cm}^{-1} .{ }^{16}$ In complexes 1-10 the $v(\mathrm{O}-\mathrm{H})$ bands are found absent as a result of deprotonation of the ligands to form these complexes. All the ligands and the complexes contain the peaks for $v(\mathrm{C}=\mathrm{N})$ and $v(\mathrm{C}=\mathrm{C})$ stretch. ${ }^{18}$ However, when these peaks from the ligands are compared to those in the complexes a slight blue shift (by a maximum of $35 \mathrm{~cm}^{-1}$ ) may be observed. In the ligands the $v(\mathrm{C}=\mathrm{N})$ appears at $1528-1546 \mathrm{~cm}^{-1}$. In the complexes the $\mathrm{C}=\mathrm{N}$ stretch values are found to appear at lower energy zones at around $1523-1539 \mathrm{~cm}^{-1}$. In the oxo-bridged $\mathrm{Mo}(\mathrm{V})$ complexes $\mathbf{1}-\mathbf{5}$ the $v(\mathrm{Mo}=\mathrm{O})$ (terminal) is observed at $935-959 \mathrm{~cm}^{-1} .{ }^{19}$ Here the effects of the donating capacity of the ligands are very obvious. It is found that the lowest energy stretching band is observed in complex 2 where the ligand is $\mathrm{HL}_{2}$, the most electron donating one. With the reduction of the electron donation capacity of the ligands this stretching frequency value gradually undergoes blue shift in 1, 3, 4 and finally has the highest value in 5 (same trend of values are observed for complexes 6-10). The antisymmetric and symmetric stretching values for bridging Mo-O are found at $799-832 \mathrm{~cm}^{-1}$ and $757-772 \mathrm{~cm}^{-1}{ }^{20}$ Here also the same correlation may be drawn. However there is not much difference in these peaks when the chloro complexes are compared to the bromo complexes of the same ligand showing that both the chloro and bromo donors are weakly bound and contributes little to the stability of the complexes.

Electronic spectra of the complexes 1-10 in DMF display two strong absorption bands in the region 293-312 nm and 329-355 $\mathrm{nm}$. These peaks may be assigned as charge transfer transitions of the type $\mathrm{N}(p \pi)-\mathrm{Mo}(\mathrm{d} \pi)$ LMCT and $\mathrm{O}(p \pi)-\mathrm{Mo}(\mathrm{d} \pi)$ LMCT respectively, ${ }^{21}$ as the ligand based orbitals are either $\mathrm{N}$ or $\mathrm{O}$ donor types. The slight change in $\lambda$ values within each set of peaks going from $\mathbf{1}$ to 5 (and from $\mathbf{6}$ to $\mathbf{1 0}$ as well) may be due to the difference in electron donating capacity of the ligands. When $\mathrm{HL}_{1}$ is compared to $\mathrm{HL}_{3}$ and $\mathrm{HL}_{4}$ and $\mathrm{HL}_{5}$, i.e. salicylaldehyde derived ligand compared to its 5-bromosalicylaldehyde, 5-chlorosalicylaldehyde and 5-nitrosalicylaldehyde counterparts, the ligands $\mathrm{HL}_{3}, \mathrm{HL}_{4}$ and $\mathrm{HL}_{5}$ are gradually less electron-rich due to the electron withdrawing nature of the substituents. This makes HOMO of $\mathrm{HL}_{3}, \mathrm{HL}_{4}$ and $\mathrm{HL}_{5}$ higher in energy compared to that of $\mathrm{HL}_{1}$. As a result, the electronic transitions in the respective complex (3, 4 and 5) experience a red shift compared to those in 1 . On 
Table 2. Selected bond angles and bond distances of complex 1 .

\begin{tabular}{|c|c|c|c|c|c|c|}
\hline \multicolumn{2}{|c|}{ Selected bonds } & \multirow{2}{*}{$\frac{\text { Values }(\AA)}{2 \cdot 5098(10)}$} & \multicolumn{3}{|c|}{ Selected angles } & \multirow{2}{*}{$\begin{array}{c}\left.{ }^{\circ}\right) \\
89 \cdot 81(8)\end{array}$} \\
\hline Mo & $-\mathrm{Cl}$ & & $\mathrm{Cl}$ & $-\mathrm{Mo}$ & $-\mathrm{O} 1$ & \\
\hline & $-\mathrm{O} 1$ & $1.969(3)$ & $\mathrm{Cl}$ & $-\mathrm{Mo}$ & $-\mathrm{O} 2$ & $165 \cdot 63(9)$ \\
\hline Mo & $-\mathrm{O} 2$ & $1.8792(3)$ & $\mathrm{Cl}$ & -Mo & $-\mathrm{O} 3$ & $91 \cdot 11(10)$ \\
\hline & $-\mathrm{O} 3$ & $1.676(3)$ & $\mathrm{Cl}$ & $-\mathrm{Mo}$ & $-\mathrm{N} 1$ & $79 \cdot 16(7)$ \\
\hline Mo & $-\mathrm{N} 1$ & $2 \cdot 296(3)$ & $\mathrm{Cl}$ & -Mo & $-\mathrm{N} 3$ & $82 \cdot 98(7)$ \\
\hline Mo & $-\mathrm{N} 3$ & $2 \cdot 188(3)$ & $\mathrm{O} 1$ & $-\mathrm{Mo}$ & $-\mathrm{O} 2$ & $93 \cdot 36(8)$ \\
\hline & $-\mathrm{N} 2$ & $1 \cdot 380(4)$ & $\mathrm{O} 1$ & $-\mathrm{Mo}$ & $-\mathrm{O} 3$ & $101 \cdot 80(11)$ \\
\hline & & & $\mathrm{O} 1$ & -Mo & $-\mathrm{N} 1$ & $80 \cdot 02(10)$ \\
\hline & & & $\mathrm{O} 1$ & $-\mathrm{Mo}$ & $-\mathrm{N} 3$ & $151.93(10)$ \\
\hline & & & $\mathrm{O} 2$ & -Mo & $-\mathrm{O} 3$ & $101.93(13)$ \\
\hline & & & $\mathrm{O} 2$ & $-\mathrm{Mo}$ & $-\mathrm{N} 1$ & $87.59(12)$ \\
\hline & & & $\mathrm{O} 2$ & -Mo & $-\mathrm{N} 3$ & $87.69(8)$ \\
\hline & & & $\mathrm{O} 3$ & $-\mathrm{Mo}$ & $-\mathrm{N} 1$ & $170 \cdot 13(12)$ \\
\hline & & & $\mathrm{O} 3$ & $-\mathrm{Mo}$ & $-\mathrm{N} 3$ & $105 \cdot 41(11)$ \\
\hline & & & N1 & -Mo & $-\mathrm{N} 3$ & $72 \cdot 00(9)$ \\
\hline & & & Mo & $-\mathrm{O} 2$ & -Mo_a & $177 \cdot 78(19)$ \\
\hline
\end{tabular}
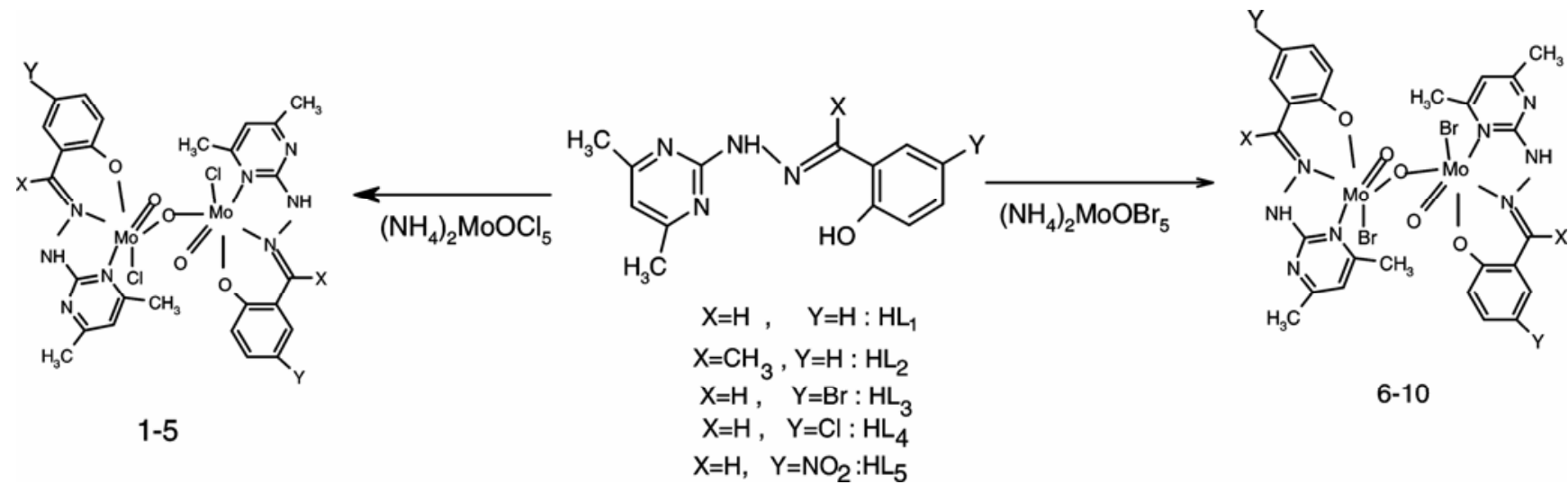

Scheme 1. Scheme showing method of preparation of complexes 1-10.

the other hand, $\mathrm{HL}_{2}$ being more e donating than $\mathrm{HL}_{1}$, the CT bands for 2 are more blue shifted compared to 1. Electronic spectra of all the complexes 1-10 in DMF solution shows another CT band at $518-556 \mathrm{~nm}^{22}$ which is characteristic of binuclear $\mu$-oxo $\mathrm{Mo}(\mathrm{V})$ complexes. None of these peaks are stable in DMF solution and disappears over a period of $24 \mathrm{~h}$ indicating solvolysis in DMF solvent. The diffuse reflectance spectra (DRS) of these complexes show a broad band implying several prominent transitions with maxima between 522 and $565 \mathrm{~nm}$. Spectroscopic characters of individual complexes are given in table S2 in the (Supplementary Information).

All the complexes were diamagnetic at room temperature and their spin paired nature did not alter with variation of temperature either. All the com- plexes were found to be EPR silent. Study of the electrochemical behaviour of the complexes was attempted using cyclic voltammetry but the results were unsatisfactory due to the instability of the complexes in DMF and DMSO.

\subsection{Structure of complex 1}

The neutral $\mu$-oxomolybdenum(V) complex 1 (figure 1) bears a distorted octahedral geometry around each Mo atom. The ligand $\mathrm{HL}_{1}$, in its deprotonated form occupies three of the six coordination sites at the metal centre. One terminal oxo atom, one bridging oxo atom and a chloride ion complete the coordination spheres. The tridentate monoanionic donor ligand $\left(\mathrm{L}_{1}^{-}\right)$binds the molybdenum(V) centre through a pyrimidine nitrogen (N3), the azomethine 
nitrogen (N1) and the enolate oxygen $(\mathrm{Ol})$. The ligand forms a five-membered and a six-membered chelate ring at the metal centre in the equatorial $\mathrm{XY}$ plane. ${ }^{23}$ One oxo group (O3) is present in the same plane trans to the azomathine nitrogen. The bridging oxo group (O2) is present in the axial plane with the chloride donor. The molybdenum atoms are found to be deviated from the mean equatorial plane towards the bridging oxo group by $0 \cdot 119 \AA$ at one end of the bridge and by $0.098 \AA$ at the other end. A dihedral angle of $16 \cdot 77^{\circ}-17 \cdot 10^{\circ}$ between the pyrimidine and the phenyl ring in the bound ligand reveals that considerable deviation from planarity has taken place in the ligand to facilitate chelation. However, it may be noted that all the ligand atoms which form the two chelate rings maintain remarkable planarity to ensure adequate electron delocalization (maximum deviation $0 \cdot 150 \AA$ from their mean plane). This is unlike our previously reported dioxomolybdenum(VI) complex of the same ligand ${ }^{16}$ where the phenolate oxygen was found to be deviated by $(0.29 \AA)$ from the mean plane. The $\mathrm{Mo}=\mathrm{O}$ bond distances are unexceptional. ${ }^{24}$ As expected, the axial Mo-O bond which is also bridging in nature is longer than the equatorial one by ca. $0 \cdot 203 \AA$. The Mo-O1 bond (1.96 $\AA$ ) is longer than both Mo-O2 and Mo-O3. Between the two bonds Mo-N1 and Mo-N3 the former is a little longer due to the trans effect of the oxo group. ${ }^{25}$ The $\mathrm{Mo}-\mathrm{Cl}$ bond length of $2.51 \AA$ shows that the chloride is loosely bound. ${ }^{26}$ The bond lengths in the coordination sphere are not appreciably different from those in the previous dioxomolybdenum(VI) complex despite of the change in Mo oxidation state. Among the angles in

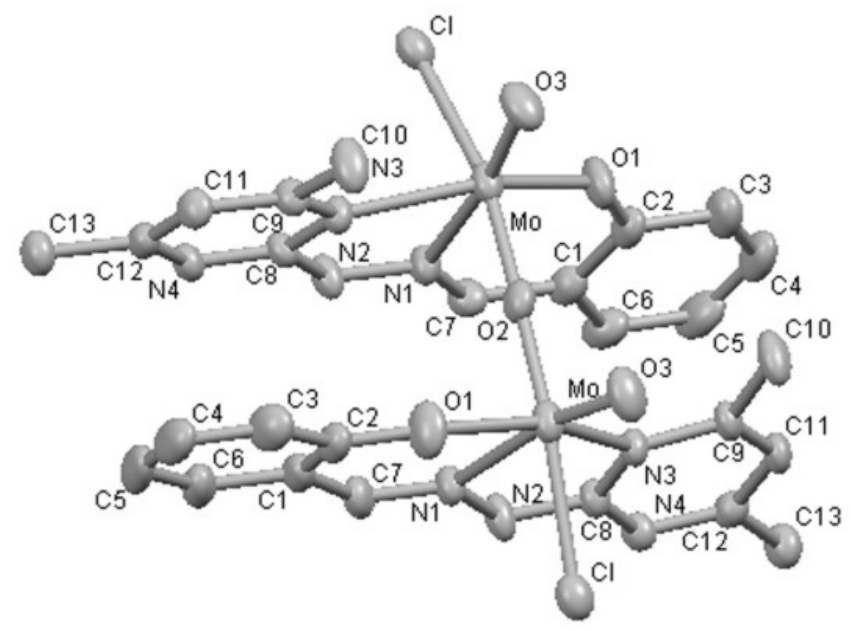

Figure 1. Structural representation of complex 1. the coordination sphere N1-Mo-O3 bears the highest value of $170 \cdot 13^{\circ}$. Values of all the other angles support in favour of distorted octahedral structure. VSEPR theory can explain the order $\mathrm{O} 3-\mathrm{Mo}-$ O1 O3-Mo-N3 $>$ N1-Mo-N3 N3-Mo-O1 and also $\mathrm{O} 3-\mathrm{Mo}-\mathrm{Cl}>\mathrm{Cl}-\mathrm{Mo}-\mathrm{N} 1$. The $\mathrm{Mo}-\mathrm{O} 2-\mathrm{Mo}$ bridge angle may have values ranging from $148^{\circ}$ to $180^{\circ}$. The low value of this angle is often associated with the presence of Mo-Mo bonding. However, higher the value, the lower is the probability of MoMo bonding. Here the bridge angle value is $177.78^{\circ}$, almost linear arrangement as in many other singly oxo-bridged $\mathrm{Mo}(\mathrm{V})$ complexes. ${ }^{27}$ This rule out any Mo-Mo bonds. The distance between the two Mo atoms (3.759 $\AA$ ) supports non bonded arrangement.

A two-fold intermolecular H-bonding interaction is observed in the complex involving the hydrogen bound to the azomethine nitrogen and the chloride donors, i.e. $\mathrm{N} 2-\mathrm{H} 2 \mathrm{~A} \cdots \mathrm{Cl}$ in the complex (figure $\mathrm{S} 1$ ). This creates an infinite one-dimensional array of $\mathrm{H}$-bonded molecules organized in a zigzag fashion. Three other unconventional ${ }^{28} \mathrm{H}$-bonding interactions of even lesser strength helps to build the three dimensional packing in the crystal. These are $\mathrm{C} 10-$ $\mathrm{H} 10 \mathrm{C} \cdots \mathrm{O} 3$ (intramolecular), $\mathrm{C} 11---\mathrm{H} 11 \mathrm{~A} \cdots \mathrm{Cl}$ and C13---H13B …03 (both intermolecular) (see table SI supplementary information). Among these three nonconventional weak $\mathrm{H}$ bonding interactions the latter two are noteworthy as the distance of interaction and the angle falls within the range required for significant contribution to the 3D structure (distance between 3.0-4.0 $(\AA)$ and angle $150^{\circ}-180^{\circ}$ ) (table SI in supplementary information). These two interactions create the binding force between the infinite one-dimensional H-bonded molecular strand. An interesting feature is the contribution made by one of the coordinated $\mathrm{Cl}^{-}$ions which gets involved in two types of weak bond interactions. A favourable configuration of the ligands bound to the Mo centers enables a two-fold intramolecular $\pi-\pi$ interaction between the pyrimidine and phenyl rings of the ligands with centroid to centroid distances of $3.52 \AA$.

\section{Conclusion}

Ten new $\mathrm{Mo}(\mathrm{V})$ complexes are prepared which are useful additions in the literature of binuclear oxobridged $\mathrm{Mo}(\mathrm{V})$ chemistry as they are based on Schiff bases derived from the biologically important heterocycle, pyrimidine. Only one of these complexes could be fully characterized as preparation of their single crystals are heavily hampered by their poor 
solubility and stability in common organic solvents. The complexes exhibit slight but perceivable changes in their spectroscopic characteristics depending on the variations of electron donating abilities of the used ligands.

\section{Supplementary information}

CCDC-678941 contains the supplementary crystallographic data for complex 1 . These data can be obtained free of charge from The Cambridge Crystallographic Data Centre via www.ccdc.cam.ac. $\mathrm{uk} /$ data request/cif. A figure showing one-dimensional $\overline{\mathrm{H}}$ bonding array of complex 1 , table showing $\mathrm{H}$-bonding parameters and spectroscopic characterization table have been presented as supplementary materials as figure $\mathrm{S} 1$, tables $\mathrm{Sl}$ and 2 (see www.ias.ac.in/chemsci).

\section{References}

1. Mendel R R 2005 J. Chem. Soc., Dalton Trans. 3404

2. (a) Hille R 1996 Chem. Rev. 96 2757; (b) Hille R 2002 Trends Biochem. Sci. 27360

3. Stiefel E I 1996 Science 2721599

4. (a) Howard J B and Rees D C 1996 Chem. Rev. 96 2965; (b) Einsle O, Tezcan F A, Andrade S L A, Schmid B, Yoshida M, Howard J B and Rees D C 2002 Science 2971696

5. (a) Ridge J P, Aguey-Zinsou K-F, Bernhardt P V, Hanson G R and McEwan A G, 2004 FEBS Lett. 563 197; (b) Ridge J P and Aguey-Zinsou K-F 2002 Biochemistry 41 15762; (c) Bernhardt P V, Brereton I M, Hanson G R, McEwan A G, McAlpine A S, McEwan A G and Bailey S $1998 \mathrm{~J}$. Mol. Biol. 275 613; (d) Dutta S K, McConville D B, Youngs W J and Chaudhury M 1997 Inorg. Chem. 36 2517; (e) Laughlin L J and Young C G 1996 Inorg. Chem. 351050

6. (a) Kirk M L 2003 ACS Symp. Ser. 858 340; (b) Enemark J H, Astashkin A V and Raitsimring A M 2003 ACS Symp. Ser. 858 179; (c) George G N 1997 J. Biol. Inorg. Chem. 2790

7. (a) Spence J T 1983 Coord. Chem. Rev. 48 59; (b) Harlan E W and Berg J M, Holm R H $1986 \mathrm{~J}$. Am. Chem. Soc. 1086992 and references therein; (c) Purohit S., Koley A P, Prasad L S and Manoharan P T 1989 Inorg. Chem. 28 3735; (d) Mondal J U, Zamora J G, Kinon M D and Schultz F A 2000 Inorg. Chim. Acta 309 147; (e) Bustos C, Burckhardt O, Schrebler R, Carrillo D, Arif A M, Cowley A H and Nunn C M 1990 Inorg. Chem. 29 3996; (g) Dinda R, Sengupta P, Ghosh S P, Mayer-Figge H and Sheldrick W S 2002 J. Chem. Soc. Dalton Trans. 4434

8. Haupt E TK, Wontorra C, Rehder D and Müller A 2005 Chem. Commun. 3912; (b) Gheller S F,
Bradbury J R, Mackay M F and Wedd A G 1981 Inorg. Chem. 20 3899; (c) Yamanouchi K, Yamada S and Emmark J H 1984 Inorg. Chim. Acta 85 129; (d) Craig J A, Harlan E W, Synder B S, Whitener M A and Holm R H 1989 Inorg. Chem. 28 2082; (e) Laï R, Desbois O, Zamkotsian F, Faure R, Feneau-Dupont J and Declerq J-P 1995 Organometallics 14 2145; (f) Cai L-Z, Song L-J, Zeng H-Y, Dong Z-C, Guo G-C and Huang J-S 2003 Inorg. Chim. Acta 34461

9. Allen F H 2002 Acta Crystallogr. B58 380

10. (a) Joshi V S, Nandi M, Zhang H, Haggerty B S and Sarkar A 1993 Inorg. Chem. 32 1301; (b) Chang C S J and Enemark J H 1991 Inorg. Chem. 30683

11. (a) Hatton A D, Malin G, Turner S M and Liss P S 1996 in Proceedings of the International Symposium on DMSP and Related Sulfonium Compounds (eds) R P Kiene and A L Mobile p 405; (b) Sambasivarao D, Dawson H A, Zhang G, Shaw G, Hu J and Weiner J H 2001 J. Biol. Chem. 27620167

12. Baird D M, Falzone S and Haky J E 1989 Inorg. Chem. 284562

13. Gupta S, Barik A K, Pal S, Hazra A, Roy S, Butcher R J and Kar S K 2007 Polyhedron 26133

14. James R G and Wardlaw W 1927 J. Chem. Soc. 2145

15. Chiswell B and Lions F 1961 Aust. J. Chem. 2271

16. Gupta S, Pal S, Barik A K, Roy S, Hazra A, Mandal T N, Butcher R J and Kar S K 2009 Polyhedron 28 711

17. (a) Kemp W 1987 Organic spectroscopy (Hamshire: Macmillan) p. 565; (b) Nakamoto K 1986 Infrared and Raman spectra of inorganic and coordination compounds (New York: Wiley) p. 241

18. Biradar N S and Havinale B R 1976 Inorg. Chim. Acta 17157

19. Pickett C, Kumar S, Vella P A and Zubieta J 1982 Inorg. Chem. 21908

20. Cendric M, Vrdoljak V, Strukan N, Tepes P, Novak P, BrbotSaranovic A, Giester G and Kemenar B 2002 Eur. J. Inorg. Chem. 2128

21. (a) Purohit S and Ghosh S P 1988 J. Chem. Res. (s) 158; (b) Hahn R, Kusthardt U and Scherer W 1993 Inorg. Chim. Acta 210177

22. Bernard K B, Bruck M, Huber S, Grittini C, Enemark J H, Gable R W and Wedd A G 1997 Inorg. Chem. 36 637

23. Craig J A, Harlan E W, Snyder B S, Whitener M A and Holm R H 1989 Inorg. Chem. 282082

24. Berg J M and Holm R H 1984 J. Am. Chem. Soc. 106 3035

25. Pramanik N R, Ghosh S P, Roychowdhury T K, Ray S, Butcher R J and Mandal S S 2004 Polyhedron 23 1595

26. Bernard K B, Bruck M, Huber S, Grittini C, Enemark $\mathrm{J}$ H, Gable R W and Wedd A G 1997 Inorg Chem. 36 637

27. Cindrić M, Matković-Čalogović D, Vrdoljak V and Kamenar B 1998 Inorg. Chem. Commun. 1237

28. Yang $\mathrm{W}, \mathrm{Lu} \mathrm{C}$, Lin $\mathrm{X}, \mathrm{Wu} \mathrm{C}, \mathrm{Wu} \mathrm{D}$ and Zhuang $\mathrm{H}$ 2001 Inorg. Chem. Commun. 4285 